\title{
The Dose Makes the Poison
}

Amy Brodtmann, MBBS, FRACP, PhD, and Aamira Huq, MBBS, FRACP

Neurol Genet 2021;7:e610. doi:10.1212/NXG.0000000000000610

Most genes cause disease when the function of at least one copy of the gene is disrupted (e.g., loss-of-function mutations) or compromised (e.g., missense mutations). Gain of function, resulting from increased dose of a gene product, is a less common mechanism of disease causation. Neurologists would be familiar with Charcot-Marie-Tooth disease type 1A caused by duplications of the PMP22 gene. Gene duplications are also well known in neurodegenerative diseases, such as duplications of the amyloid precursor protein gene (APP), resulting in earlyonset Alzheimer dementia (AD) and cerebral amyloid angiopathy (CAA), and copy number increases of the synuclein-alpha gene, SNCA, causing dementia with Lewy bodies or Parkinson disease dementia.

$A P P,{ }^{1}$ located on chromosome 21 , is the gene that produces the amyloid precursor protein (APP). This is a membrane spanning protein that is converted into smaller subunits including A $\beta$ by sequential proteolytic processing facilitated by $\beta$ - and $\gamma$-secretases. ${ }^{2}$ Overexpression of the $A P P$ gene product results in significant increases in the long isoforms of $A \beta$, overwhelming the normal clearance processes of the brain. This is posited to cause angiotoxicity (CAA) and neural synaptic toxicity $(\mathrm{AD})$. Such increased APP dosage causing cognitive decline has been implicated as the primary cause of early onset $\mathrm{AD}$ observed in people with Down syndrome (trisomy 21), where there is increased APP gene dosage. ${ }^{3}$ Multiple cases of APP gene duplications have now been reported in people with early-onset $\mathrm{AD}$.

In this issue of Neurology ${ }^{\otimes}$ Genetics, Grangeon et al. ${ }^{4}$ present a case report where a 41-year-old man with episodic memory loss onset at 39 years is found to have a novel heterozygous triplication of the $A P P$ gene, most likely inherited from his father. Although duplications of the gene APP have been described before, this is a report of a triplication. The proband in this report developed memory impairment associated with lobar microbleeds identified on MRI. His CSF biomarkers showed decreased amyloid- $\beta_{42}$ levels with increased total-tau and phosphorylated-tau levels. He fulfilled the clinical diagnostic criteria of probable $\mathrm{AD}$ associated with neuroimaging features consistent with CAA. Of interest, his father had had seizures and recurrent cerebral hemorrhages beginning in his late thirties, and cerebral biopsy showed abundant perivascular amyloid deposits. The father's clinical features and investigations were also consistent with early-onset $\mathrm{AD}$ and probable CAA. He died at age 48 years, and no DNA was available for analysis.

The messenger RNA (mRNA) analysis in the study by Grangeon et al. highlights the importance of dosage sensitivity of the APP gene product. Using reverse transcription digital droplet PCR, they were able to show that the gene triplication in their patient translated into proportionately increased expression of APP. The patient with the triplication (4 copies instead of the expected 2 copies of the APP gene) had doubling of the APP mRNA levels. Although they were not able to make direct comparison with patients with APP duplications, people with duplications ( 3 copies of $A P P$ ) have a reported a 1.5-times increase in APP mRNA levels. The age at onset of symptoms in the patients is also slightly lower than prior APP duplication reports (37 and 39 years vs 39-65 years), which could indicate a correlation of severity with increased gene dosage.

\author{
Correspondence \\ Dr. Brodtmann \\ agbrod@unimelb.edu.au
}

\section{RELATED ARTICLE}

Early-Onset Cerebral

Amyloid Angiopathy and

Alzheimer Disease Related

to an APP Locus

Triplication

Page e609 
The strength of the study lies in the clear phenotyping and the mRNA quantification in the proband. Unfortunately, only 2 family members in this pedigree were available, with confirmation of the APP triplication present only in one of them. Further genetic analyses, including looking at other $\mathrm{AD}$ and $\mathrm{CAA}$ risk genes, would have been important to truly understand the clinical expression associated with the increased copy numbers of the $A P P$ gene. This is especially pertinent as some animal studies have suggested that elevated cerebral $A \beta$ deposition can occur in trisomy 21 independent of an extra copy of $A P P$, indicating that other genes in chromosome 21 may affect this pathway. ${ }^{5}$ Moreover, this case report does not shed any new light onto the pathophysiology of CAA in the majority of people with CAA and cognitive decline, who do not have $A P P$ copy number increase.

For clinicians involved in the care of patients with a strong family history of $\mathrm{CAA}$ and early-onset $\mathrm{AD}$, the main message from this study is to consider referral for formal genetic testing for APP gene copy number variations. Many commercially available next generation type of gene panels may not have the capacity to simultaneously look for copy number variants and therefore may miss this diagnosis. If the laboratory does not cover copy number variant analysis, a specific test such as a chromosomal microarray or multiplex ligation-dependent probe amplification should be organized.

Despite large clinical trials targeting $A \beta$ and its pathways, disease modification for $\mathrm{AD}$ currently remains elusive.,7 Polygenic and multifactorial contributions to late-onset $\mathrm{AD}$ are the norm, but the early onset, monogenic forms are likely to benefit from ongoing pursuit of the amyloid pathway in clinical trials. Moreover, the effect of $A \beta$ pathway modulators has not been specifically studied in individuals with increased $A P P$ gene dosage, which allows new possibilities for treatments using a precision medicine approach. Studies such as this one open a gateway into understanding both the pathology and potential disease modifiers in this unique subgroup of patients.

\section{Study Funding}

No targeted funding reported.

\section{Disclosure}

The authors report no disclosures relevant to the manuscript. Go to Neurology.org/NG for full disclosures.

\section{References}

1. Revesz T, Holton JL, Lashley T, et al. Genetics and molecular pathogenesis of sporadic and hereditary cerebral amyloid angiopathies. Acta Neuropathol. 2009;118(1): 115-130.

2. Thinakaran G, Koo EH. Amyloid precursor protein trafficking, processing, and function. J Biol Chem. 2008;283(44):29615-29619.

3. Mrak RE, Griffin WS. Trisomy 21 and the brain. J Neuropathol Exp Neurol. 2004; 63(7):679-685.

4. Grangeon L, Cassinari K, Rousseau S, et al. Early-onset cerebral amyloid angiopathy and Alzheimer disease related to an APP locus triplication. Neurol Genet. 2021;7(5):e609.

5. Wiseman FK, Pulford LJ, Barkus C, et al. Trisomy of human chromosome 21 enhances amyloid-beta deposition independently of an extra copy of APP. Brain. 2018; 141(8):2457-2474.

6. Alves S, Fol R, Cartier N. Gene therapy strategies for Alzheimer's disease: an overview. Hum Gene Ther. 2016;27(2):100-107.

7. Huang LK, Chao SP, Hu CJ. Clinical trials of new drugs for Alzheimer disease. J Biomed Sci. 2020;27(1):18. 


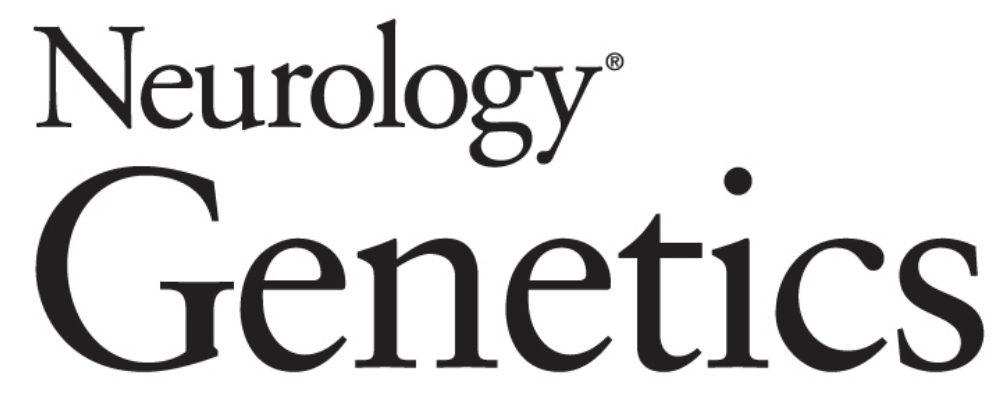

The Dose Makes the Poison

Amy Brodtmann and Aamira Huq

Neurol Genet 2021;7;

DOI 10.1212/NXG.0000000000000610

This information is current as of September 8, 2021

Updated Information \& Services

References

Subspecialty Collections

Permissions \& Licensing

Reprints including high resolution figures, can be found at: http://ng.neurology.org/content/7/5/e610.full.html

This article cites 7 articles, 2 of which you can access for free at: http://ng.neurology.org/content/7/5/e610.full.html\#\#ref-list-1

This article, along with others on similar topics, appears in the following collection(s):

\section{All Genetics}

http://ng.neurology.org//cgi/collection/all_genetics

Alzheimer's disease

http://ng.neurology.org//cgi/collection/alzheimers_disease

Information about reproducing this article in parts (figures,tables) or in its entirety can be found online at:

http://ng.neurology.org/misc/about.xhtml\#permissions

Information about ordering reprints can be found online: http://ng.neurology.org/misc/addir.xhtml\#reprintsus

Neurol Genet is an official journal of the American Academy of Neurology. Published since April 2015, it is an open-access, online-only, continuous publication journal. Copyright Copyright $\odot 2021$ The Author(s). Published by Wolters Kluwer Health, Inc. on behalf of the American Academy of Neurology.. All rights reserved. Online ISSN: 2376-7839.

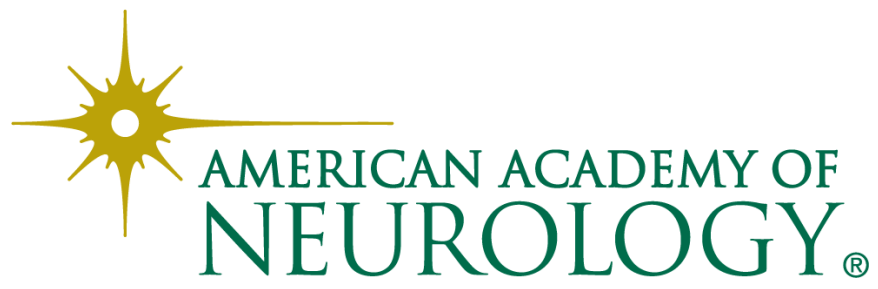

